\title{
Do Simplified Text Can Improve Students' Reading Comprehension in Narrative Text?: A Classroom Action Research Perspective
}

\author{
Suwondo Suwondo \& Syaifullah Syaifullah \\ Universitas Lancang Kuning. Pekanbaru. Indonesia \\ syaifullah@unilak.ac.id
}

\author{
Received : 2019-07-01 \\ Revised : 2019-07-11 \\ Accepted : 2019-10-18
}

ARTICLE HISTORY

\section{KEYWORDS}

Reading

Simplified text

Narrative text

Students' reading skill

\begin{abstract}
This research was based on the researcher's preliminary study which found that the students could not comprehend the meaning of texts in their textbook. This Classroom Action Research (CAR) aims to improve the students' reading comprehension in narrative text through simplified text at grade VIII of SMP Budhi Luhur Pekanbaru. The research was administered to the second year students of SMP Budhi Luhur Pekanbaru. The total population was 34 students. After analyzing the data, the researcher found a significant effect of simplified text toward reading at the second-year SMP Budhi Luhur Pekanbaru students, where the average score from the based score was 58. It increased to 66 at the end of the cycle I. Finally, the average score of cycle II was 75. So it can be concluded that simplified text can increase the students' reading skill at grade VIII SMP Budhi Luhur Pekanbaru
\end{abstract}

\section{Introduction}

English is one of the subjects in Junior High School and it is taught in every class for at least four hours a week. At the end of the English teaching and learning process, it is hoped that the students will perform English in both spoken and written effectively. In speaking, the students are hoped to be able to communicate with other people in English. Meanwhile, in writing, they can convey their ideas or messages through various kinds of writing products. In English subject, four skills should be taught. One of them is reading, a crucial skill for English as a Second Language (ESL) and English as a Foreign Language (EFL). In terms of teaching reading, the students are expected to develop their comprehension, which enables them to grasp the message provided by the writer. Students need to comprehend reading in order to get knowledge and information. In other words, the aim of reading is to comprehend the messages.

Based on the researcher's Teaching Practice Experience in February to April 2015 at class VIII SMP Budhi Luhur most students did not have adequate reading comprehension. When the teacher asked them to read a text and then answer the questions that followed, most were challenging to answer the questions correctly. There are several potential causes of this condition: the learners themselves, the teacher's strategy, teaching material, and the classroom's atmosphere. From the researcher's Teaching Practice Experience, the students of class VIII were passive during reading class. They spent too much time finding the meaning of words in the dictionary and asked their friends.
Consequently, they did not have enough time to do reading comprehension exercises. Having enough vocabularies determine a student's success in comprehending reading material. Another problem has found in the student's passiveness. They just listened to the teacher and seldom asked questions. Although the teacher is good and teaches in a good strategy, teaching and learning cannot be achieved if the students were passive in learning reading text. Further, this condition will be supported by the teacher herself, who teaches friendly and communicatively. In this research, the researcher focused on narrative texts, which the teacher had simplified. This kind of text was taught from the first grade until the third, but grade eight students still have low reading comprehension.

Derived from the identification of the problems described above, the students are hoped to comprehend reading text. Therefore, the researcher focuses on improving students' reading comprehension in narrative text through simplified text by formulation two major questions in this presents research; (1) To what extent can Simplified Text improve the students' reading comprehension of narrative texts at class VIII SMP Budhi Luhur Pekanbaru?, and (2) What factors influence the changes in Students' Reading Comprehension of Narrative Text of Class VIII of SMP Budhi Luhur Pekanbaru?

\section{Literature Review}

Reading is a fluent reader process combining information from a text and their background knowledge to build meaning (Nunan. 2003). He 
divides reading into two: 1) Strategic reading; and 2) Fluent reading. Strategic reading is defined as the reader's ability to use a wide variety of reading strategies to accomplish a purpose for reading, while fluent reading is defined as reading at an appropriate rate with adequate comprehension. So we can infer that reading can be divided into two, but it is Strategic Reading for the use of academic. Moreover, according to Abraham (1987), reading is the most valuable skill. He also considers that: 1) reading is essentially deriving or getting meaning from written or printed form of language, 2) reading is a two-way process because, in order to derive meaning from what he/she reads, the reader must bring meaning to what he reads, 3) reading involves associating the shape of a word or sentence with its meaning, 4) reading is a complexity of the skill. Based on these statements, it is clear that the reading process involves the activities to get the meaning, mainly it can be applied to the students.

Furthermore, Scovel (2001) also says that reading is not 'simple' or 'passive' activities because it requires much complex and active mental processing as it more physically involves speaking and writing. This statement is compatible with Pakhare (2007). She says that a person having good comprehension skills is considered an active reader, with an ability to interact with the words by understanding their whole meaning and the concept behind them. So, by comprehending reading, the reader can have good comprehension skills it enhances their active mental processing skills.

Narratives construct a pattern of events with a problematic and unexpected outcome that entertains and instructs the reader or listener. Narratives entertain because they deal with the unusual and unexpected development of events. They instruct because they teach readers and listeners that problems should be confronted and attempts to resolve them. (English K-6 Modules, 1998). A narrative is a piece of writing that tells a story. The story may be either fiction or non-fiction. Examples of fiction include realistic fiction, science fiction, mysteries, folk tales, fairy tales, and myths. Non-fiction is fact-based text such as reports, factual stories, and biographies. The primary purpose of the narrative is to entertain, to gain and hold a readers' interest. However, narratives can also be written to teach or inform, change attitudes/social opinions, e.g. soap operas and television dramas used to raise topical issues (Features of Text Forms).

A narrative text can have as many paragraphs as the writer wants. However, it mainly consists of three parts: orientation, sequence of events/complications and resolution (Narrative Texts Strategies). The narrative text has five standard components. Most test questions refer to one of these five-story elements (Narrative Text Strategies):

1) Setting: A story can be set in the present, past, or future. Some stories are set in faraway lands or imaginary places, others set in familiar places. Authors may tell the reader the exact time or place of the story, but often these must be inferred by the reader.

2) Characters: People or animals in the stories.

3) Plot: The plot of the story is the sequence of events. The story's plot takes the reader through events that build to a climax or turning point in the story. The author then brings the story to a resolution. At times, an author may allow the reader to draw his conclusion about resolution.

4) Theme: The theme is the central idea of the story. A theme can be directly stated or through the use of story elements.

5) Vocabulary: The author uses vocabulary to enhance the reader's understanding of characters and events in the story. The author's choice of vocabulary produces the mood and tone of the story.

These five components can be used to read narrative text indicators because the students will be given several questions such as setting questions, character questions, plot questions, theme questions, and vocabulary questions.

Simplified text is text that has been modified, enhanced, and classified. It can reduce ambiguity, improve reading comprehension for people whose first language is not English, and facilitate computerassisted translation and machine translation. It is also expected to be used by people with language disabilities like aphasic because aphasic, in general, has trouble with long sentences, few words and complicated grammatical constructs and passive voice; users of limited channel devices because the devices have a small screen with limited space to display the text.

Researchers has revealed that input to non-native speakers is adjusted or modified. There are two types of modifications: (a) simplification and (2) elaboration. Simplification has widely been used in many commercially published L2 reading materials under the belief that the use of controlled vocabularies and short, simple sentences will facilitate L2 reading comprehension (Urano,, 1998).

\section{Method}

This research was action research because this research tried to improve students' reading comprehension. As Gay (2000) says that action research is a type of practitioner's practice; action implies doing or changing something. Action research is a process in which individuals or several teachers collect evidence and make decisions about their knowledge, performance, beliefs, and effects to understand and improve them. The researcher analyzed the data by using quantitative and qualitative data analysis. 


\subsection{Quantitative Data}

From the quantitative data that was gain through the test, the researcher made a test based on indicators of scoring in reading. To assess the students' Reading Ability, the researcher used the pattern as below:

$$
\mathrm{P}=\frac{\text { Mean score }}{\text { Maximum score }} \times 100 \%
$$

The categories were as follows (Harris, 1969, p.134)

Table 1. The score categories

\begin{tabular}{cc}
\hline Score & Level of Ability \\
\hline $80-100$ & Good to excellent \\
$60-79$ & Average to good \\
$50-59$ & Poor to average \\
$0-49$ & Poor \\
\hline
\end{tabular}

\subsection{Qualitative Data}

In order to analyze the observation checklist, field note, and interview researcher used the qualitative data as follows :

a) Data managing: Data got from the observation and interviewed managed to get a good result and easy to analyze.

b) Reading the note: Here, the researcher read all fields notes found out during the researcher sincerely.

c) Description: It aimed to provide an accurate picture of the setting, and that took place on it. So, the researcher and reader had an understanding of the result.

d) Classifying: the data is categorized into a smaller unit based on the data and field note found during the research.

Interpreting: In this step, the data was interpreted into a general conclusion or general understanding.

\section{Findings}

Comparing the reading based score and cycle I, there was an improvement in cycle I did not pass the passing score (KKM). Also, in cycle II, it could be seen that Simplified Test could improve the students reading ability. The comparison of the test results in every cycle as follow:

Table 2. Students' Level in Comprehending Narrative Text

\begin{tabular}{cccccc}
\hline No & Test & Poor & $\begin{array}{c}\text { Poor- } \\
\text { Average }\end{array}$ & $\begin{array}{c}\text { Average - } \\
\text { Good }\end{array}$ & $\begin{array}{c}\text { Good - } \\
\text { Excellent }\end{array}$ \\
\hline 1. & $\begin{array}{c}\text { Base } \\
\text { Scor } \\
\text { e }\end{array}$ & $\begin{array}{c}14,70 \\
\%\end{array}$ & $47,06 \%$ & $38,24 \%$ & $0 \%$ \\
2. & $\begin{array}{c}\text { Cycl } \\
\text { e I }\end{array}$ & $0 \%$ & $11,76 \%$ & $64,71 \%$ & $23,53 \%$ \\
3. & $\begin{array}{c}\text { Cycl } \\
\text { e II }\end{array}$ & $0 \%$ & $17,64 \%$ & $44,12 \%$ & $38,24 \%$ \\
\hline
\end{tabular}

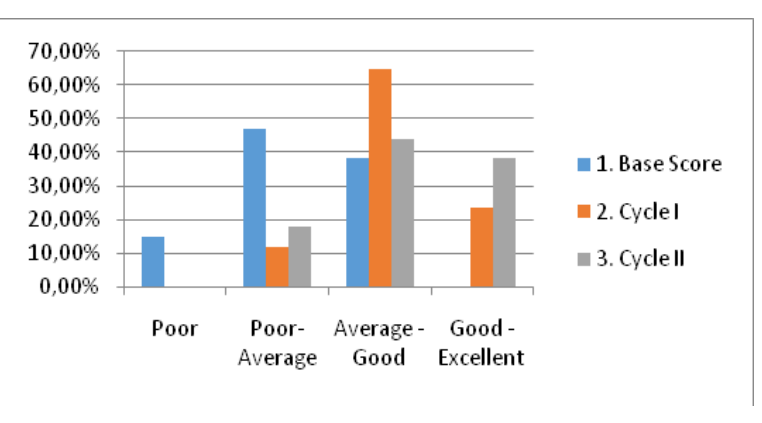

Figure 1. Students' Score

The students' base score in comprehending narrative text was dominated by Poor-average level of ability, there were $47,06 \%$ of the students, but at the second test, the percentage decreased. It becomes $11,76 \%$, and at the end of the test, the poor-average level became $17,64 \%$. The poor level percentage was about $14,70 \%$ at the first test and became $0 \%$ at the second and the third test. Then, the average-good level percentage was increased from $38,24 \%$ in the first test to $64,71 \%$ in the second test, and it becomes $44,12 \%$ in the third test. The good-excellent level was $0 \%$ in the first. It was increased from $23,53 \%$ at the second test and $38,24 \%$ at the third test.

The improvement reached by the students was also influenced by the students' ability in applying the strategy that the researcher had taught by using Simplified Text. The students' successes in applying this strategy had been mention in chapter II. The students could also understand the researcher explains about the materials. Besides, the researcher also helped the students solve their problems in comprehending narrative text by using Simplified Text. All of the students have worked together. They could follow all of the steps of Simplified Text.

\subsection{The Factors Influenced the Improving Students' Reading Ability}

In this step, the researcher would like to discuss some factors in students' reading ability using Simplified Text. During the teaching and learning process, when the researcher researched, some factors were found in using simplified text in comprehending narrative text at grade VIII SMP Budhi Luhur Pekanbaru. The factors that influenced the improving students' reading ability could be concluded from internal and external factors. It could be drawn as in the following statements.

\subsubsection{Internal Factors}

This present research during the time frame of the research could figure out some factors that can trigger the student's ability in reading narrative text lies from internal factor:

a) Motivation. It could be seen during research time, researcher and students gain an improvement because they were found motivated to learn English by using simplified text. In the end, the students achieved a 
good result. The fact of motivation exists proved existed as the factor as being recorded in the interview session two that revealed that "The students were easy to understand the story of Narrative Text by using Simplified Text". The interview took place at SMP Budhi Luhur grade VIII on Saturday, June 6, 2015, at $10 \mathrm{am}$. The researcher interviewed the students. It proved that the students got better learning that could increase the positive result by improving the teaching technique, which the researcher then conducted.

b) Interest. The exciting material designed also became a factor that supported the learning process of students in the class. The students' interest increased while studying reading using simplified text because the researcher already simplified the text. It proved that the students were enthusiastic about learning reading.

c) The Material. The students were enjoyed and fun learning English because they got a new strategy to improve their reading ability, especially narrative text. It could be proved that students were excited to learn reading by using simplified text because they did not get a new strategy before.

\subsubsection{External factors}

Form the external factors which influenced the improvement of students' reading ability:

a) First was the researcher's attitude also giving an impact improvement of students' reading ability because the researcher was willing to help and explain to the students about narrative text by using simplified text. The researcher also gave a reward for students who were active in class. It made the students were happy and enjoyed learning reading, and they were more excited to learn and active in class.

b) Second, in comprehending narrative text, it could be inferred that simplified text made the students had enjoyable and fun learning with the researcher's reading material. It could be seen that the students were active to answer questions from the teacher. They were fun to learn to read.

c) Third, the students were enthusiastic about learning reading because the researcher already simplified the text. It could be proved the students were easy to understand the text hence they would like to learn new reading material.

\section{Conclusion}

This present study sees that, simplified text can improve students' reading comprehension in the narrative text at grade VIII SMP Budhi Luhur Pekanbaru. It could be seen from the average score from the base score was 58. It increased cycle I and cycle II 66 and 75.

While, the factors which influence the changing of students' reading comprehension of narrative text by using simplified text are followed by :
1) The students can improve their reading ability by applying the teacher's technique in teaching narrative text. It could be seen from the observation done by the collaborator,

2) From field notes, we can see that the students are actively discussing in their group since it could allow them to share their ideas because the reading material which the researcher gave was interesting, so they were not bored and active in learning narrative text because the text had already been simplified.

3) The students had a good interaction with the researcher, and it could enhance their willingness to speak bravely by using English with the teachers' help. So the students were more enjoyable and fun in learning to read narrative text. It could be concluded from the interview conducted by the researcher.

\section{References}

Abraham, D. (1990). Planning and Teaching, Practical Suggestion for English in the Classroom. Penerbit Fajar Bakti Sdn. BHD. Kuala Lumpur.

Carroll, J., Minnen, G., Canning, Y., Devlin, S., \& Tait, J. (1998, July). Practical simplification of English newspaper text to assist aphasic readers. In Proceedings of the AAAI-98 Workshop on Integrating Artificial Intelligence and Assistive Technology (pp. 7-10).

Creswell, J. (2005). Educational Research (Second Edition): Planning, Conducting and Evaluating Quantitative and Qualitative Research. New Jersey: Pearson Education

Gay, L. R., \& Airasian, P. W. (2000). Instructor's manual to accompany Educational research: competencies for analysis and application. Merill.

Hadley, G. (Ed.). (2003). Action research in action. SEAMEO Regional Language Centre.

Harris, D. P. (1993). Testing for Language Teachers. Cambridge, University Press.

Inui, K., Fujita, A., Takahashi, T., Iida, R., \& Iwakura, T. (2003, July). Text simplification for reading assistance: a project note. In Proceedings of the second international workshop on Paraphrasing (pp. 9-16).

Newmark, P. (1988). A textbook of translation (Vol. 66). New York: Prentice hall.

Nunan, D. (2003). Practical english. Language Teaching. New York: Mc Graw Hill.

Pakhare, J. (2007). Effective teaching: Reading comprehension strategies. Retrieved July, 20, 2013.

Rosa Lini, D. R. (2011). The Use of Information Gap Activity to Increase Speaking Ability of Second 
Year Students at SMA N 3 Pekanbaru. The University of Riau.

Scovel, T. (2001). Learning new languages: A guide to second language acquisition. Boston, MA: Heinle \& Heinle.

Siddharthan, A., Nenkova, A., \& McKeown, K. (2004). Syntactic simplification for improving content selection in multi-document summarization.

Urano, K. (1998). Negative pragmatic transfer in compliment responses by Japanese learners of English. Unpublished manuscript, University of Hawai'i at Manoa, Honolulu. Retrieved May, , , 2006. 